\title{
LIVING HADITH: THE PHENOMENA OF FIDYAH PRAYER AND FASTING TRADITION IN INDRAMAYU
}

\author{
Masri Mansoer \\ Syarif Hidayatullah State Islamic University (UIN) Jakarta \\ masri.mansoer@uinjkt.ac.id \\ Atiyatul Ulya \\ Syarif Hidayatullah State Islamic University (UIN) Jakarta \\ atiyatul.ulya@uinjkt.ac.id \\ Nurkholis Sofwan \\ Syarif Hidayatullah State Islamic University (UIN) Jakarta \\ nurkholis.sofwan12@yahoo.com
}

\begin{abstract}
This article explains the phenomenon of fidyah sholat and fasting tradition in Indramayu. Generally, fidyah prayer which is performed by the society still raises a quite heated controversy. It is different from the "fidyah fasting" which has been agreed upon the whole Muslim society. From those debated ideas, the people in Indramayu still perform the tradition in a various way. One of them is the "fidyah" with specific rituals, such as the fidyah in the way of rotating back and forth the rice or money (Geong), the fidyah which is given before a corpse is prayed, and the fidyah on the seventh day of the death of a person.
\end{abstract}

Keywords: Living Hadith, Tradition of Fidyah Prayer and Fasting, Indramayu

\section{Introduction}

In the Social Religious Stratification, Muslim Society desires an ideal religious life by following the Prophet Muhammad traditions. (al-Na'īm, 2004: 35) Even though the prophet has passed away, his traditions are still as ideal ones for the followers and are followed by the following generations which are adjusted to their dynamical needs. A continuing and progressive interpretation, according to M. Alfatih Suryadilaga, is called as living sunnah. It is $\mathrm{wh}$ at $\mathrm{h}$ as $\mathrm{h}$ appe $\mathrm{ned}$ in $\mathrm{Middle}$ East a rea s u ch a s Hijaz, Egypt dan Irak. (Suryadilaga, dkk, 2006: 193) The prophet traditions in its development have been verbalized in the form of texts which is codified as the book of Hadith.Until recently, Hadith as the second source of Islamic teaching after the Qur'an, is followed and practiced in the life of society to become a tradition that preserved continually. One of the traditions is the tradition of fidyah sholat and fidyah fasting.

In Indonesia, the tradition of fidyah sholat and fasting are only performed by the society in certain areas. This is due to the debate among local ulama regarding to the legitimacy of fidyah sholat and fasting. (Nawawī al-Bantanī. N.d.: 192-193; Syațā al-Dimyāțī. N.d.: 24, Aḥmad al-Saqāf, n.d.: 1) Regardless of the debate, however Muslims in Indonesia are still enthusiastic in performing the tradition of fidyah sholat and fasting in their environments. One of them is Muslims in Indramayu. According to local ulama, $\mathrm{t}$ he tradition of fidyah sholat and fasting comes from the prophet traditions and books of fiqh. In some area in Indramayu, the tradition of fidyah is performed by rotating the rice back and forth from 
inherited to guardian, and then from the guardian to the poor and so on. This tradition is known as "Geong". Beside Geong ritual, the tradition of fidyah in some other area in Indramayu is performed without special ritual, for example the rice used for fidyah is given to the people participated in the tradition of the seventh days ritual of a person's death (tahlilan). There is also another fidyah tradition performed by giving the rice to the poor before the corpse is prayed and buried. The phenomenon is fidyah sholat or fasting for people who have died because of having obligations of sholat or fasting. (Fieldwork in Tenajar Lor Village, Kertasemaya Sub-District, Indramayu regency, July 2016)

\section{The History Fidyah Tradition in Indramayu}

The fidyah tradition which is known as Geong has existed since the day before the independence of Indonesia, that is around 1900s. The starting figure who plays a role in spreading fidyah tradition in Tenajar Lor village was $\mathrm{Ki}$ Qamus. The emergence of fidyah tradition in Indramayu does not exist by it self, since the tradition is closely related to the obligatory of sholat and fasting of a deceased. There are two reasons in substituting the obligatory of sholat and fasting of the deceased by giving fidyah: First, fidyah sholat is an obligated syariat that must be performed in case the deceased ever made a last will (to give fidyah) during his life. Second, in case the deceased did not make a last will to give fidyah, so fidyah sholat and fasting is merely ihtiyat from the family/the guardian. Therefore, even though the deceased did not have a will to give fidyah, however people still show their concern for the deceased, that is by showing the attitude of birr al-walidain (do righteous deeds to the parents), so that people continue to practice fidyah tradition in their environment as ihtiyat. (Interview with Rokhmat, Tenajar Lor Village, Kertasemaya Sub-District, February 2, 2017)

Generally, fidyah tradition is the result of people interpretation of Islamic doctrine toward the Qur'an, Hadith, and fiqh books. Therefore the spread of fidyah tradition can not be separated from the role of kyai and pesantren as an Islamic learning area in community. Both are the main sources in spreading the fidyah tradition, especially in Indramayu. Based on the result of interview, the figures spreading fidyah tradition are the people of Indramayu who studied in various pesantren such as in Lirboyo (Kediri, East Java), Kaliwungu (Kendal, central java), Sarang (Rembang, Central Java), Pesantren Kempek (Cirebon, West Java), Pesantren Babakan Ciwaringin (Cirebon), and so forth. After graduating from the pesantren, then Santri teach their knowledges to the society by holding the study of "Kitab Kuning" (classical fiqh literature), Qur'anic interpretation, Hadith, et cetera. So that the society affirmed the Santri as "Kyai" or a person who has deep religious knowledge. (Interview with Mahya Hasan, Head of Section of Madrasah Diniyyah, Minsitry of Religious Affairs, Indramayu Regency, March 2, 2017)

The people of Indramayu, especially the people in Tenajar Lor, Sliyeg Lor, and Segeran Kidul acknowledged that the implementation of fidyah tradition had been performed from generation to generation. They convince that the tradition was spread by the Santris who studied the book of Hadith and fiqh. They proved it by showing some books as the references in fidyah tradition. Among them are the books of Tarsīkh al-Mustafìdinn, I'ānah al- Tälibīn, and Nihāyah al-Zaīn. These books serve as a reference for Islamic 
studies in some places such as pesantren, mosques, and musholla in their villages. (Interview with Kyai Badrudin, January 30, 2017) Besides these books, the practice of fidyah tradition is also strengthened by using Hadith related to fidyah sholat and fasting, (Alī ibn Sinān bin Bahr al-Khurasānī al-Qādī, 1991: 175), and Hadith describing the obligation to pay off the debt of a deceased. (al-Bukhārī, ND: Hadith no. 2127)

\section{Living Hadith in Fidyah Tradition}

Based on the result of observation and interview conducted toward the people of Indramayu, it shows that they understand the Hadith of fidyah sholat and fasting as an ihtiyat (prudence). According to them sholat and fasting is an obligation that should not be abandoned. Since sholat is a very important worship, they try to cover up the lack of sholat of their family who died with giving fidyah. According to Rokhmat, one of leaders in Tenajar Lor Village, it is closely related to caring attitudes and the ihtiyat of the family to substitute sholat left by the deceased. (Interview with Rokhmat, February 2, 2017) However there are some people who do not know precisely the text of Hadith related to fidyah sholat and fasting. Their knowledge about the implementation of fidyah sholat and fasting is limited to the kyai and local community leaders' suggestions that the deceased is advised to give fidyah sholat and fasting from his property or the family of the deceased. (Interview with Yusroh April 28, 2017) Kyai Badrudin, one of ulama in Tenajar Lor village, stated that the abandoned sholat and fasting of a deceased should be substituted by the family. Sholat and fasting is a form of worship to God, so the obligation to God must be fulfilled as described in the Hadith of the prophet Muhammad saw. (Interview with Kyai Badrudin, January 30, 2017) The Hadith is understood as a suggestion to fulfill the obligation of the deceased by the family, especially the obligation in worshiping Alloh swt. The obligation of worship to Alloh Swt is something more to be fulfilled, such as fasting, performing Haj, and sholat. (Șahịh Muslim, ND: Juz 3: 155, Hadith 2750) This opinion is also understood by Rokhmat, he analogized as follows:

Man is given "opportunity" of life for fifty years, so with that long time one is given an obligation to worship God. When one does not fulfill his obligation to God, then Alloh will demand him in the hereafter life.(Interview with Rokhmat, February 2, 2017)

Thus, public confidence toward the obligation of sholat and fasting of dead person that can be substituted with fidyah can be strongly claimed. Because the people of Indramayu believe that their fidyah will accomplish the deceased. Among the books and propositions they use to assert that their fidyah is beneficial to the deceased is the book of I'anah alṬâlibīn (Syațā al-Dimyāṭī, ND: 559) and the Qurean surat al-Ḥasyr ayat: 10. The verse shows that the living person can pray for the deceased, and the prays are believed can accomplish the deceased. This is also supported by a Hadith from al-Bukhari describing that the prophet Saw prayed a dead person, by plugging in a wet midrib of palm leaf on ones grave to ease his torture in the afterlife. (al-Bukhārī, ND: Hadith No. 5)

From this Hadith it can be understood that the deeds and prays of the prophet Saw are convinced that it can give benefits to the deceased and can ease his torture. This is also believed by Syaikh al-Islam Ibn Taimiyah. He affirms that prays and good deeds of the deceased, then the rewards from Alloh can accomplish him. (Ibn Taymiyyah, 1978, Jil. 24: 306) Therefore, it is not surprising that religious traditions such as tahlilan, haul, attaqa, including fidyah sholat and fasting for the dead person, became a habit of 
Indramayu community and is always preserved, especially among the people of Nahdliyyin.

\section{The Practice of Fidyah tradition in Indramayu}

From the result of observation and interview to the Indramayu community, the meaning of Hadith and ""kitab kuning" raises some model of fidyah tradition. In this case, there are three models of fidyah sholat and fasting tradition in Indramayu, i.e., Fidyah in Geong ritual, Fidyah pre-sholat for the corpse, and Fidyah post-tahlilan.

\section{a. Geong (Rotating back and forth)}

One model of performing fidyah sholat and fasting for a dead person is by rotating back and forth which is called geong. The aim is to fulfill the desired time target of the giver of fidyah in order to fulfill the obligation of sholat of his deceased relatives with his property. (Interview with Rokhmat, February 2, 2017) This kind of fidyah is one's ihtiyat to fulfill the obligation of sholat in a lifetime with his existing treasure. The least rice or money a person has in giving a lifetime fidyah can be initiated by rotating it as long as the age of the deceased. For instance, the family can only give as much as 5 quintals of rice, while fidyah to be given is as long as 45 years. So the five quintals of fidyah which is only enough for five years, can be rotated from heirs to guardians, then from guardians to the poor, and from the poor to guardians, and so on until 45 years. (Interview with Kyai Badrudin, January 30, 2017)

This kind of fidyah can be found in Tenajar Lor village, Kertasemaya, Indramayu. In general, the model of fidyah in the way of rotating back and forth (geong) is a kind of rare and unique one. Since the fidyah sholat and fasting tradition which is counted for a lifetime as an ihtiyāt has a determination, es ist., when the fidyah is for women, so it is minus the period of menstruation, nifas, and baligh period, whereas if it is for men, so it is only reduced the period of baligh. (Ahmmad al-Saqāf, $N D: 143$ )

In the beginning, the fidyah tradition in this village used rice, but in its development today, many of Tenajar Lor village community have used money to give fidyah as a substitution for rice. This replacement is based on some reason such as effectiveness and the easier in the process of implementation of fidyah ritual. The permissibility of the replacement of rice into money was also based on the opinion of Imam Abu Hanifa in the classic books that they studied. (Interview with Rokhmat, February 2, 2017)

\section{b. Fidyah Pre-Shalat of a corpse}

Fidyah as a substitution of sholat or fasting for the deceased has its own time in the implementation. The implementation of Fidyah at a certain time has its own motive. As in the Village Segeran Kidul, Segeran, fidyah performed before the corpse is being prayed in sholat. The family of the deceased prepared the rice of fidyah to be distributed to the poor in the surrounding environment. According to Ust.Shofwan, one of the Ulama of Segeran Lor Village, mentioned that the motive of the implementation of fidyah before the corpse being prayed in sholat is based on the hadith of the Prophet who describes that the Prophet did not pray the corpse until someone fulfills it. (Interview with Shofwan, April 27, 2017)

The Hadith indicates that the giving of fidyah is similar to a debt, and is categorized as mu'amalah that must be paid by the person who owes, because he will be accounted for it in the hereafter. So that if the person who owes died, then for the family, it is suggested to 
pay off the debts of the deceased before he was prayed. (al-Bukhārī, Șaḥịh al-Bukhārī, Hadith 212) Based on this Hadith, some villagers of Segeran Kidul also believes that payment of fidyah as a substitution for the obligation of sholat and fasting of a died person had to be fulfilled before the corpse was prayed. This is as stated by Yusroh, one of the villagers of Segeran Kidul, who entrusted the management of fidyah to the local ulama, Ust.Shofwan in redeeming the obligation of sholat and fasting of her late husband. Whereas one of the sunnah convinced by local ulama is based on the above Hadith is fulfilling the obligation before the corpse being prayed. Therefore, Yusroh also gave the rice of fidyah sholat and fasting to the poor eligible neighbors before the body of her husband was prayed. (Interview with Yusroh, April 28, 2017)

\section{c. Fidyah Post-Tahlilan}

Tahlilan is a religious tradition inherent in Nahdliyyin society to pray to the deceased. In Sliyeg Lor Village, Sliyeg, Indramayu, tahlilan is usually accompanied by the tradition of fidyah sholat and fasting. This post-tahlilan fidyah model is usually performed on the 7th day after the death of a person. Everyone invited to follow tahlilan, is given food and rice of fidyah as redemption on the sholat and fasting that has been left by the deceased. H.Zainuddin, one of the community leaders of Sliyeg Lor village, stated that the tradition of distributing rice of fidyah when tahlilan has been completed has occurred in hereditary in his environment. The distribution of rice by shahib al-bayt (the host) is intended to give fidyah sholat and fasting from the family of the deceased. (Interview with H. Zainuddin, April 26, 2017)

In practice, the people of Sliyeg Lor village also do the same calculation, one mud for one sholat time, and one mud for one fasting day. Unlike the fidyah in the geong ritual, fidyah sholat and fasting in this village is calculated from sholat and fasting which is known to be abandoned by the deceased. In other words, fidyah sholat and fasting are not counted for a lifetime. But, they distributed the rice of fidyah sholat and fasting to those who follow tahlilan, and it is distributed after the tahlilan activities were completed.

\section{Society Respons Toward Fidyah Tradition in Indramayu}

Indramayu people who carry out the tradition of fidyah sholat and fasting for their families who have died have different experiences. From the results of interviews, after implementing fidyah tradition, some people feel that they have shown ta'abbud attitude to the God, some other people respond it casually, and there are some who feel burdened. According to Rokhmat, the fidyah that he carried out is solely as evidence that he cares for his parents (birr al-walidain) and is a worship (ta'abbud) to Allah SWT. He considers that one's sholat are not always right, some are rare in performing sholat and some other perform it well and rightly. Since sholat is an obligation (fardu), the debt of sholat according to him must be paid with fidyah. (Interview with Rokhmat, February 2, 2017) However, the people of Indramayu do not all agree with the existence of fidyah sholat, especially the fidyah model with the rotation back and forth (geong) and the model in which are distributed at the time of tahlilan. Their disagreements are not without reason, that is because: First, the fidyah with the model of rotation back and forth (geong) does not have a strong proposition, but it is merely a local tradition. Secondly, in practice, not all who are invited to follow the fidyah tradition are poor, but those who are in accustomed to following the tradition and those who are fluently in reciting the ijab qabul (akad) in the fidyah tradition. This causes the fidyah 
that should be given to the right of the poor, to be less precise in its distribution. Therefore, they more agree if the practice fidyah is directly given to those who needs.

This is as revealed by Akhid, that fidyah sholat is not taught in the Qur'an and Hadith. According to him, if indeed there is a Hadith about fidyah sholat then the validity of the Hadith should be re-examined, the intent and purpose or asbab al-wurud of the Hadith must also be known. He also thinks that the Hadith may be related to politics or the like, so for him the Hadith is doubtful. He stated that sholat is a worship that can not be replaced with anything else, sholat must be performed even in sickness condition, as has been explained in the Hadith of the prophet Muhammad saw. (Sunan Abī Dāwud, 1994: Juz 3, 142, Hadith No. 815.) For his statement, he still does not want to carry out the tradition of fidyah (Geong) even though there are community leaders who suggest to do it. Nevertheless, he still respects the people who carry out the tradition, and come every time he is invited to follow the tradition for social reasons. (Interview with Akhid, January 31, 2017 )

In line with the above opinion, Widodo also assumes that the fidyah sholat has no proposition, it is in contrast to the fidyah fasting which has a strong proposition in the Qur'an Surat al-Baqarah verse: 184 . As a person living in a society that majority carry out the fidyah tradition, He still blends in the society by following the religious traditions in his environment.

As well as fidyah tradition, he is suggested to perform fidyah sholat and fasting as his parents did in their neighborhood. Economically, he feels burdened with the rule of fidyah since he has to spend hundreds liter of rice. Nevertheless, he still follows the "parent" rule for the social reasons, and his fidyah is intended to be a sadaqah. (Interview with Widodo, March 4, 2017)

According to H. Abbas Abdul Jalil, one of the community leaders of Segeran Kidul Village, stated that majority of Segeran villagers, especially the Nahdliyyin, carried out the fidyah tradition. The community of Segeran Kidul Village is divided into two groups, namely Nahdlatul Ulama (NU) and Muhammadiyah. Although both of the groups are different, the people who belong to these groups remain harmonious. In this case, there is no debate or controversy in their social life of religion in its environment, including in the case of fidyah tradition. They can live side by side with mutual respect for each other. (Interview with $\mathrm{H}$. Abbas Abdul Jalil, April 27, 2017) It is also acknowledged by H. Zakariya, one of the villagers of Segeran Kidul, that the Muhmmadiyah people still respect the neighbors who follow NU's deeds. As in the case of fidyah sholat, Muhammadiyah group does not recognize it, while NU is on the contrary, but each group respects each other by allowing the Nahdliyyin people to practice their own deeds and Muhammadiyah group do their deeds without blaming each other. (Interview with H. Zakariya, April 28, 2017)

\section{Conclusion}

The phenomenon of fidyah sholat and fasting tradition in Indramayu is a phenomenon of living hadith. Indramayu people understand the hadith about fidyah sholat and fasting as ihtịast (caution). Some references used as guidelines in implementing the tradition is the Qur'an, hadith, and books of fiqh. People's interpretation of religious literature, especially the Hadith, found three phenomena of living hadith of fidyah, i.e; fidyah by rotating back and forth (geong tradition), fidyah pre-shalat of a corpse, and fidyah posttahlilan. 


\section{References}

Al-Bukhārī, Abū, Abd Allāh Muḥammad bin Ismā'īl bin Ibrāhīm. N.y. al-Jāmi ‘ al-Bukhārī (Sahīh al-Bukhārī) Bairut: Dār al-Fikr.

Al-Dimyāṭ̂̄, Ab̄̄ Bakr Ibn al-Sayyid Muḥammad Syațā. Nd. I'ānah al-Ṭālibīn. Bairūt: Dār al-Fikr.

Al-Na'īm, Abd Allah Ahmad. 2004. Dekonstruksi Syariah, Penerjemah: Ahmad Suaedy dan Amirudin al-Rany. Yogyakarta: LKis.

Al-Qādī, Abū Abd al-Raḥmān Aḥmad bin, Alī ibn Syu'aīb bin, Alī ibn Sinān bin Bahr alKhurasān̄̄. 1991 M/1411 H. Sunan al-Nasa'̄̄ al-Kubrā, Muhaqqiq: Abd al-Ghaffār Sulaymān al- Bandārī, Juz 2. Bairūt: Dār al-Kitab al- Ilmiyyah.

Al-Qusyairī, Abū Husain Muslim bin al-Ḥajjāj. N.y. Șaḥ̄h Muslim. Bairut: Dar al-J̄̄ll.

Al-Saqāf,al-Sayyid. Alwī Ibn al-Sayyid Aḥmad. N.y. Tarsīkh al-Mustafìdīn, Bairūt: Dār al-Fikr.

Al-Sijistān̄̄, Abū Dāwud Sulaymān bin al-Asy'ats. 1994. Sunan Ab̄̄ Dāwud.Bairut: Dār al-Fikr.

Suryadilaga, M. Alfatih. et al, 2006. Metodologi Penelitian Hadith. Yogyakarta: Pokja Akademik UIN Sunan Kalijaga.

Taimiyah, Ibn. 1978. Majmu’ al-Fatawa, Jil.24. Beirut: al-Maktab al-Islami.

Al-Tāwidī, Ibn Abd al-Mu'țā Muhammad bin Umar bin Alī Nawawī al-Jāwī alBantan̄i. N.y. Nihāyah al-Zaīn: fì Irsyād al-Mubtadi'̄̄n. T.Tp: Syarikah al-Nūr Asiā.

Woodward, Mark R. 2017. Islam Jawa: Kesalehan Normatif Versus Kebatinan, Penerjemah: Hairus Salim HS. Yogyakarta: IRCiSoD.

\section{Interview:}

Interview with H.Abbas Abdul Jalil, Segeran Kidul Village, Juntinyuat Sub-district, April 27, 2017.

Interview with Akhid, Tenajar Lor Village, Kertasemaya Sub-district, Januari 31, 2017.

Interview with H.Sayyidi, Sliyeg Lor Village, Sliyeg Sub-district, April 26, 2017.

Interview with H.Zakariya, Segeran Kidul Village, Juntinyuat Sub-district, April 28, 2017.

Interview with Kyai Badrudin Tenajar Lor Village, Kertasemaya Sub-district, Januari 30, 2017.

Interview with H.Zainuddin, Sliyeg Lor Village, Sliyeg Sub-district, April 26, 2017.

Interview with Mahya Hasan, Indramayu Regency, March 2, 2017.

Interview with Rokhmat Tenajar Lor Village, Kertasemaya Sub-district, February 2, 2017.

Interview with Ust.Shofwan, Segeran Kidul Village, Juntinyuat Sub-district, April 27, 2017.

Interview with Widodo, Sliyeg Lor Village, Sliyeg Sub-district, March 4, 2017.

Interview with Yusroh, Segeran Kidul Village, Juntinyuat Sub-district, April 28, 2017. 